\title{
Medicine by correspondence in Newfoundland and Labrador, 1911
}

\author{
- Cite as: CMAJ 2020 June 1;192:E612-3. doi: 10.1503/cmaj.191589
}

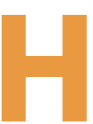

istorical correspondence between patients and physicians offers insights into the way people thought about health and sickness, as well as the relationships between providers and those seeking care. In eighteenth-century Europe, for example, doctors did not consider a physical examination necessary for establishing a diagnosis. ${ }^{1,2}$ Instead, patients often articulated their troubles in the form of a consultative letter. Even as physical contact between patients and practitioners became standard practice, medicine-bypost remained common for rural patients, for whom the journey to visit an urban physician might be impossible. ${ }^{3}$

Rural Newfoundland and Labrador has been described historically as "scattered pockets of people living in outports that quite literally [clung] to the coastline," 4 spread thinly to exploit the rich marine resources. Many communities were consistently accessible only by boat well into the twentieth century. Dr. (and later Sir) Wilfred Thomason Grenfell, the charismatic and prolific British medical doctor, was inspired by the plight of the sick in Labrador and northern Newfoundland. He signed up with London's Royal National Mission to Deep Sea Fishermen, working from 1892 to build a vast network of hospitals, hospital ships and nursing outposts along the sparsely populated and woefully underserved coasts of Newfoundland and Labrador.

A group of residents representing settlements that surrounded Notre Dame Bay wrote an impassioned plea to Grenfell in 1910, appealing to his "human and philanthropic consideration" to create a branch of the Fishermen's Mission in the area, which had "in the past experienced and suffered in no very impalpable degree consequent upon the want of a resident doctor." ${ }^{5}$ It was reasoned that a new

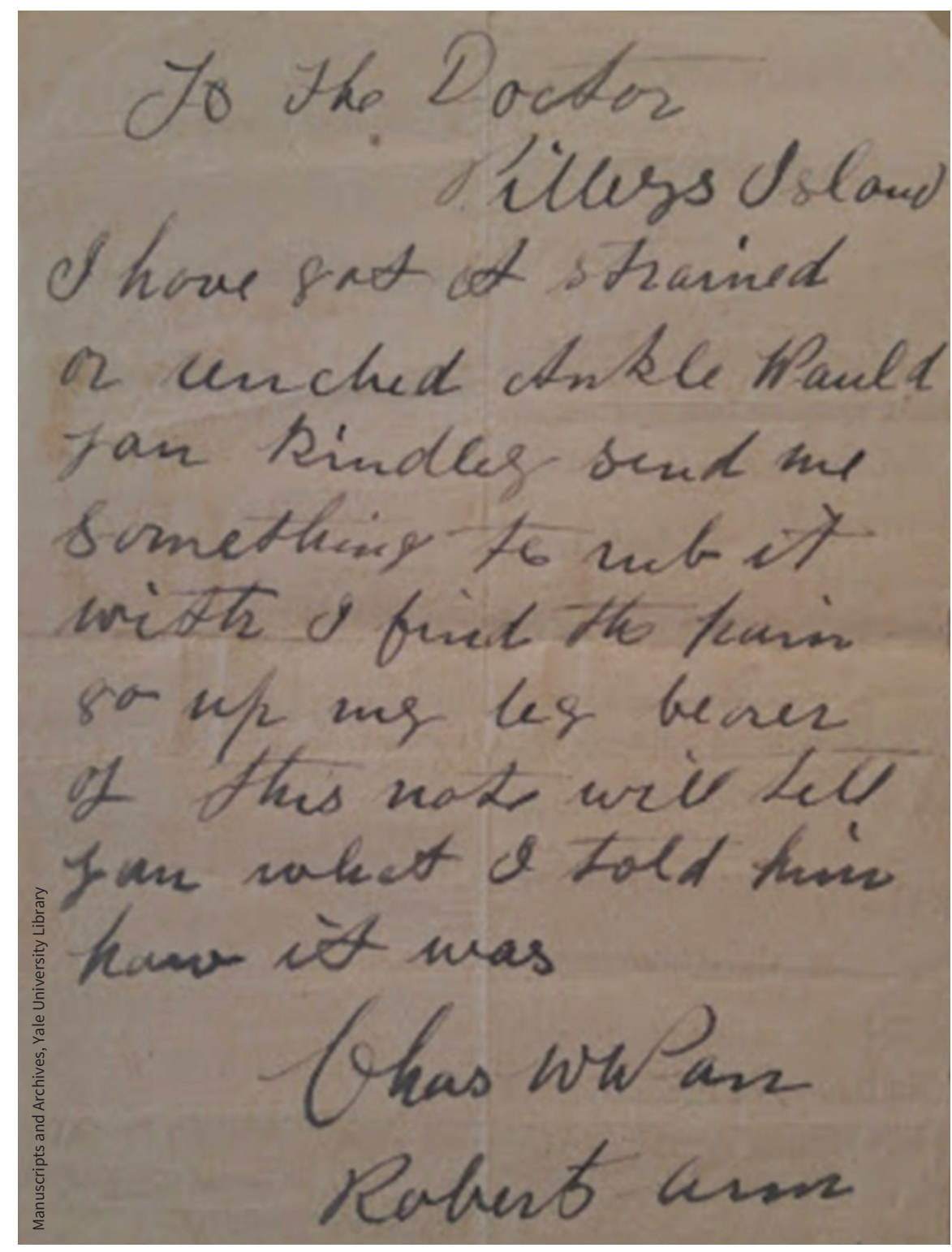

Figure 1: Consultative letter sent to Dr. Hugh Greeley (Hugh Payne Greeley papers [MS1472])

hospital at Pilley's Island, Notre Dame Bay, could reduce the number of individuals requiring transport to the larger hospitals of St. John's and St. Anthony, located at opposite sides of the island. The belief was this could reduce costs and temper the stress of family members who might send off their loved ones to suffer and possibly die far from home. ${ }^{6}$ In 1911 , this settlement, site of a pyrite mine from 1887 to 1908 , was a fishing and lumbering community of 688 individuals. $^{7}$ 
Grenfell appealed to the sense of adventure of two young Americans, physician Dr. Hugh Greeley and surgeon Dr. Harrison Briggs Webster: two "first-class young medical men volunteering their services." 8 Upon their arrival at Pilley's Island in May 1911, Greeley commented that the inhabitants had saved up "the darndest lot of ailments" 5 as he encountered myriad cases of typhoid, measles and tuberculosis, in addition to surgical conditions that ranged from the pedestrian (tonsillectomy) to the acute (appendectomy). Farther-flung patients were heartened by the arrival of a doctor, but the punishing weather and challenging topography - much travel was possible only by snowshoe or dog team - made personal visits infrequent.

Greeley, therefore, conducted a portion of his practice via correspondence; 15 such letters have survived, curated by the Yale University Library Manuscripts and Archives, providing direct access to the historical patients' concerns (Figure 1). Four are quoted here exactly as written, patient voices from more than a century ago:

I am sending for you come at once if possible My son has taken very badly with fitts last evening he takes with a roaring pain in the pit of the Stomac and goes to the right Side and after that pain goes away he take a wonderful fitt which take 5 or 6 men to hold him.

Come at once + do your best

and oblige

Mr. James J. Snow (4 June 1911, Woodfords Cove)

Hubert's condition is about the same as when you saw him the last morning, I think. His temperature this week in the afternoons has been from 102 degrees to $1024 / 10$, his pulse 80 to 88 .

He has complained of a slight soreness in the abdomen after a movement of the bowels and sometimes he complains of quite a little fulness.

He is still drowsy and stupid sometimes but is more easily aroused than when first he was taken ill.

He had a slight sore throat yesterday but says it is better today.

I keep his mouth cleaned regularly, his tongue is looking fairly good, appetite is fair. I am still keeping him in bed, although he would like to sit up part of the day.

Yours truly,

L. Strong (19 August 1911, Little Bay Island)
The swelling of my feet, and legs do not inconvenience me much as it is mostly confined to the feet, but lately I find a slight swelling at the bottom of the abdomen, and around the passage. I suppose this is all due to the one cause, so I rest nearly all the time, as it lessens the swelling. Hoping my arrangement is satisfactory,

I remain

Yours very sincerely

Mrs. Richard Byrne (24 August 1911, Fortune Harbour)

I am ritting to let you know all my meddison is gone and I dont feel no better but a little worse so I like to have some more if you pleas.

William Whalen (24 December 1911, Leading Tickles) ${ }^{9}$

These missives provide a direct view into the lives and anxieties of rural patients. Toothaches, sores, bedwetting and general debility are described in the other documents, as well as anxieties about bill payments and prescription refill requests for ointments, upset-stomach remedies and carbolic powders for wound care. Thomas Power, describing his inconsistent "flow of water," highlights the responsibility of the patient to represent a complex illness narrative succinctly, signing off: "I think I have explained to [you] as well as I can." Equally apparent is the expectation of physician action: "I would like you to do your best + write me as soon as possible." 9 Several letters include details of prognoses, indicating a reciprocated correspondence; unfortunately, none of Greeley's replies have been discovered to date. Others make mention of the doctor's last visit, showing that letters were supplementary to inperson consultations, rather than direct replacements. Because patients, according to Greeley's fee structure, "are visited in their home at the rate of fifty cents a mile" and "medicine is dispensed at rates only slightly above cost," 5 it was financially prudent of rural patients to communicate via post regarding refills or chronic concerns.

The voices and personalities captured in these letters have echoes in the history of epistolary medicine, wherein the documents themselves become tangible "legacies of relationships." ${ }^{10}$ Indeed, correspondence with physicians has deep historical roots as a means of maintaining relationships, asserting the individuality of symptoms and evoking sympathy and action. Patients in the past and today "employ many different voices to solicit medical attention," ${ }^{1}$ showing their understanding of their critical role in medical encounters, both in person and by post.

\section{Madeleine Mant PhD}

Department of Anthropology, University of Toronto Mississauga, Mississauga, Ont.; Department of Archaeology, Memorial University of Newfoundland, St. John's, NL

\section{Andrew Prine MD}

Groves Memorial Community Hospital, Fergus, Ont.

\section{References}

1. Wild W. Doctor-patient correspondence in eighteenth-century Britain: a change in rhetoric and relationship. Stud Eighteenth Cent Cult 2000; 29:47-64. doi: 10.1353/sec.2010.0288.

2. Pilloud S, Louis-Courvoisier M. The intimate experience of the body in the eighteenth century: between interiority and exteriority. Med Hist 2003;47:451-72.

3. Lane J. 'The doctor scolds me': the diaries and correspondence of patients in eighteenth century England. In: Porter R, editor. Patients and practitioners: Lay perceptions of medicine in preindustrial society. Cambridge (UK): Cambridge University Press; 1985:205-48.

4. Connor JTH. 'Medicine is here to stay': rural medical practice, the northern frontier and modernization in 1930s' Newfoundland. In: Connor JTH, Curtis S, editors. Medicine in the remote and rural north, 1800-2000. London (UK): Pickering and Chatto; 2011:129-51, 130.

5. Greeley HP, Greeley FE. Work and play in the Grenfell Mission: extracts from the letters and journals of Hugh Payne Greeley M.D. and Floretta Elmore Greeley. New York: Fleming H. Revell Company; 1920:192 p.

6. Rompkey R. Grenfell of Labrador. Montréal (QC): McGill-Queen's University Press; 2009:169.

7. Newfoundland Colonial Secretary's Office. Census of Newfoundland and Labrador, 1911: Table 1, population, sex, condition, denomination, profession, etc. St. John's: J.W. Withers; 1914: 212

8. Greeley (Hugh Payne) Papers. MS1472 Box 1 Folder 1. Correspondence 1910-11. Letter to Mr. L.S. Ruel from Dr. Wilfred T. Grenfell, Apr. 17, 1911. Yale University Archives.

9. Greeley (Hugh Payne) Papers. MS1472 Box 1 Folder 5. Patients' letters 1911-12. Yale University Archives.

10. Dolan B, Goren N, Perlis C. Epistolary medicine. Lancet 2009;374:1588-9.

This article has been peer reviewed.

Competing interests: None declared. 